\title{
THE USE OF MOUSE MODEL FOR THE DETERMINATION OF PROTECTIVE ACTIVITY IN SALMONELLA-SPECIFIC LEUCOCYTE DIALYZATE
}

\section{MIKULA and J. PISTL}

Department of Microbiology, Immunology and Animal Hygiene, University of Veterinary Medicine, 04181 Košice

Received June 6, 1988

\begin{abstract}
Mikula I., Pistl J.: The Use of Mouse Model for the Determination of Protective Activity in Salmonella-specific Leucocyte Dialyzate. Acta vet. Brno 58, 1989: 281 - 296.

The specific Leucocyte dialyzate (DLEs) was prepared from the peripheral blood leucocytes, mesenteric lymph nodes and spleens of calves that have been vaccinated and subsequently infected with virulent $S$. typhimurium strain. The non-specific dialyzate $\left(D^{2} E^{n}\right)$ was obtained from the lymph nodes of fattened bulls. The inhibition of Salmonella penetration into the liver and spleen as well as the colonization of digestive tract were tested in SPF white mice and C57BL/6 inbred mice to which DLE was administered and then were infected with $S$. typhimurium strain. The application of DLEs induced a marked inhibition and/or elimination of penetrative abilities of virulent $S$. typhimurium strain in white mice. In C57BL/6 inbred mouse line, DLE partially inhibited multiplication of salmonellae in the liver and spleen, respectively. DLE ${ }^{n}$ did not inhibit the penetration and colonization of salmonellae.

The standardization of DLE preparations was carried out by measuring of optical density at $260 \mathrm{~nm}\left(\mathrm{OD}_{260}\right)$. The solution of specific DLE at $\mathrm{OD}_{260}$ of 1.5 (10-fold concentrated) inhibited and/or eliminated the penetration and colonization properties of $S$. typhimurium.

The fractionation of DLEs through Sephadex G-25 confirmed heterogeneity of fractions in the protection against salmonellosis. The index ratio of $\mathrm{OD}_{260}$ to $\mathrm{OD}_{280}$ as tested for Sephadex fractions showed different values than in the case of DLE preparation.
\end{abstract}

Leucocyte dialyzate (DLE), Salmonella typhimurium, immunity, mice.

Dialyzable leucocyte extract (DLE) characterized as a preparation obtained by disruption of leucocytes (concentrated in "buffy coat") can also be isolated from the lymph nodes and spleens and after dialysis DLE contains low-molecular components with a great part of them formed for example by thymosin (Wilson 1983). The compound from DLE with molecular weight of approximately 3500 daltons presents 
antigen-specific transfer factor (TF) (Fudenberg 1986). In the present, the term "transfer factor" is used for dialyzable low-molecular leucocyte components that can mediate the T-lymphocyte response of antigen-specific nature (Wilson and $\mathrm{Fu}$ denberg 1983). The enzymatic studies characterized TF as complete in vivo molecules composed of RNA base and peptides. The disruption of these molecules resulted in the loss of biological activity (Wils on et al. 1976).

DLE is able to transfer not only positivity in the skin test but is also responsible for the production or initiation of other reactions of cell-mediated immunity in various immunodeficient conditions (Levin 1970). Immunity induced with DLE is characterized by production of migration-inhibition factor (MIF), by stimulation of macrophages and lymphocytes.

The unit for testing of DLE efficiency is defined as amount of DLE obtained from $5 \times 10^{8}$ leucocytes (Khan et al. 1979). The potency unit is defined as DLE amount which can induce $20 \%$ antigen-specific inhibition of leucocyte migration (Fuden. berg 1980; Wilson et al. 1982). The other methods for in vitro testing of DLE efficacy are as follows: transformation of lymphocytes (Ablin 1980), E-rosette test, tests for phagocyte activity and chemotaxis activity (Arala-Chaves et al. 1977).

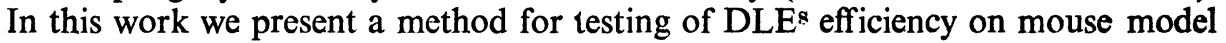
enabling to characterize a minimum inhibition dose of Salmonella-specific DLE and protective activity in Sephadex fractions as well.

\section{Materials and Methods}

Experimental animals

Conventional white SPF mice and C57BL/6 mouse inbred line (VELAZ, ÚSOLPraha) were used in our experiments.

Dialyzable leucocyte extract

a) DLEs was prepared from the peripheral blood leucocytes (concentrated in "buffy coat"), mesenteric lymph nodes and spleens of calves immunized against salmonelosis with "Salinvak" vaccine (made in Czechoslovakia) and subsequently infected with S. typhimurium (Fig. 1). Lymph nodes and spleens following homogenization and 10 -fold cryolysis were centrifuged at $10000 \mathrm{~m}$. s. ${ }^{-2}$. Supernatant was subjected to filtration through whirling asbestic-cellulose filter (Seitz K3) and filtrate was dialyzed against distilled water containing $0.1 \%$ maltose at $4^{\circ} \mathrm{C}$. Dialyzates concentrated by freeze-drying were resuspended and purified through Amicon apparatus fitted with UM5 membrane. As for testing of efficient dose, DLE was diluted to the values of $0.35,0.6,0.8,1.0$ and 1.5 at $\mathrm{OD}_{260}$ as well as for 5-, 10-, 50- and 100 -fold values at $\mathrm{OD}_{260}$ that equals to 1.5 . DLE determined at $\mathrm{OD}_{280}$ corresponded to $0.8-1.0$ values.

b) Non-specific DLE was prepared from the bull's lymph nodes and spleens. Fattening bulls were immunized by a mixture of viral and bacterial antigens used for the production of serobronchin (product made by Bioveta, Nitra).

\section{Gel chromatography}

Fractionation of DLE was carried out through Sephadex G-25 column $(2 \times 45 \mathrm{~cm})$ eluted with Tris- $\mathrm{HCl}$ buffer $(\mathrm{pH} 7.2)$ at a flow rate of $0.1 \mathrm{ml} \mathrm{min} .^{-1}$ and $4^{\circ} \mathrm{C} .100$-fold concentrated sample of $3 \mathrm{ml}$ volume was logded on column (original $\mathrm{OD}_{260}=1.8$ ). The individual $3 \mathrm{ml}$ fractions were collected and following $\mathrm{OD}_{260}$ and $\mathrm{OD}_{280}$ measurements were stored in frozen condition until further testing. 
mePARATION OF LEUCOCVTE DIALYSATE

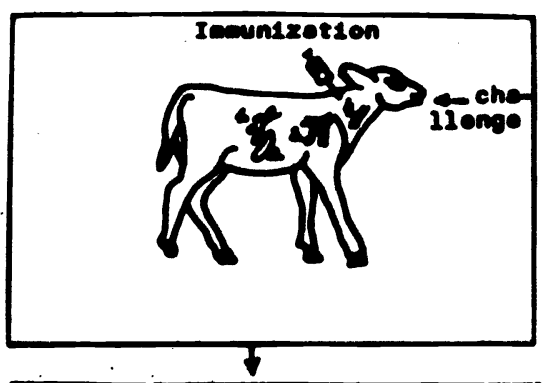

VIELIOIM OF EROLOOICAL mienial

1. moenser1c 2 yaph nodee

2. Modreotinal I yaph nodoe

3. SPLEEN

4. Porlphorel blood

1

PR OCESSING

A. Monosenzzation - Froezing and them of Trssues

( 1-3) wim orelo

- Conerifugation

- separation

- F1ltrotion of

ano Isclation eupargatane

or (rmmicerTES (4)

- Dielyeis of 11trate eapant dietsiled wetor

APrIIcatron

- Concentration mepa-

- Lymphocyto d1 RATION Pector)

- Fsleretion through one1beterial ister 
DLE application

DLE measured at the respective $\mathrm{OD}_{260}$ concentration as well as the fractions selected from the gel chromatography were filtrated through antibacterial filter G5 and then applied intraperitoneally to mice in volume of $0.5 \mathrm{ml}$.

\section{Infection of mice}

Mice were orally infected with $S$. typhimurium $4 / 5$ strain at a dose of $10^{3} \mathrm{CFU}$ (colony forming units).

\section{Testing for DLE efficiency}

10-fold concentrated DLE $\left(\mathrm{OD}_{260}=1.8\right)$ was i.p. administered to mice (Tab. 1). Mice in the total number of 220 were divided into 6 groups. Mice from the 1st, 3rd and 5th groups following DLE application were infected with $S$. typhimurium $4 / 5$ after 24 hours. Mice out of the 2nd, 4 th and 6th groups were infected on day 7 after DLE administration. DLEs was given to mice of the 1st up to 4th groups and DLEn

\begin{tabular}{|c|c|c|c|c|c|c|c|c|c|c|c|}
\hline & \multirow{3}{*}{$\begin{array}{l}\text { enoup or } \\
\text { rece }\end{array}$} & \multicolumn{10}{|c|}{ DARAMETERS OF TEST } \\
\hline & & \multicolumn{2}{|l|}{ LCO } & \multicolumn{4}{|c|}{ munes or rece } & \multicolumn{2}{|c|}{$\begin{array}{l}\text { ORAL IMFECTION } 8 \text {. } \\
\text { TrMERMARIUN } 4 / 8\end{array}$} & \multicolumn{2}{|c|}{$\begin{array}{c}\text { KILLING of Mace } \\
\text { POSTIMFECTION }\end{array}$} \\
\hline & & $\begin{array}{l}\text { oose/mouse } \\
\text { (a1) }\end{array}$ & 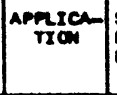 & $\begin{array}{l}\text { speck- } \\
\text { ixc } \\
\text { Led }\end{array}$ & c & $\begin{array}{l}\text { now } \\
\text { spes- } \\
\text { exc } \\
\text { Les }\end{array}$ & c & $\begin{array}{l}\operatorname{logs} / 0,2 \\
\text { al (crut) }\end{array}$ & 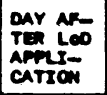 & Dars & $\begin{array}{l}\text { SAMPLES } \\
\text { COLLEC } \\
\text { TED }\end{array}$ \\
\hline $\begin{array}{r}1 / A \\
k \\
2 / A \\
k\end{array}$ & $\begin{array}{l}\text { WITE SWF } \\
\text { WHITE SPF } \\
\text { WIITE SW } \\
\text { WITE SWF }\end{array}$ & $\begin{array}{c}0,8 \\
\text { plocubo } 0,8 \\
0,8 \\
\text { plocebo } 0,8\end{array}$ & 1.p. & $\begin{array}{r}20 \\
- \\
20 \\
- \\
\end{array}$ & $\begin{array}{l}- \\
20 \\
- \\
20\end{array}$ & $\begin{array}{l}- \\
- \\
- \\
-\end{array}$ & $\begin{array}{l}- \\
- \\
-\end{array}$ & $\begin{array}{l}10^{3} \\
10^{3} \\
10^{3} \\
10^{3}\end{array}$ & $\begin{array}{l}1 \\
1 \\
7 \\
7\end{array}$ & $3,6,9,30$ & $\begin{array}{l}\text { LIVER } \\
\text { SMLER } \\
\text { oUr }\end{array}$ \\
\hline $\begin{array}{r}3 / 4 \\
k \\
4 / 4 \\
K\end{array}$ & $\begin{array}{l}\cos \alpha / 6 \\
\operatorname{cs} 7 \alpha / 6 \\
\operatorname{cs} \alpha \alpha / 6 \\
\operatorname{cs} \alpha \alpha / 6\end{array}$ & $\begin{array}{c}0,0 \\
\text { Pleceos } 0,0 \\
0,0 \\
\text { Plecebo } 0,0\end{array}$ & 2.p. & $\begin{array}{r}20 \\
- \\
20 \\
-\end{array}$ & $\begin{array}{l}-1 \\
20 \\
20\end{array}$ & $\begin{array}{l}- \\
- \\
-\end{array}$ & $\begin{array}{l}- \\
- \\
- \\
-\end{array}$ & $\begin{array}{l}10^{3} \\
10^{3} \\
10^{3} \\
10^{3}\end{array}$ & $\begin{array}{l}1 \\
1 \\
7 \\
7\end{array}$ & $3 ; 6,9,30$ & $\begin{array}{l}\text { LIVER } \\
\text { SPLEEN } \\
\text { GUT }\end{array}$ \\
\hline $\begin{array}{r}6 / A \\
k \\
6 / A \\
k\end{array}$ & $\begin{array}{l}\text { WHITE SPF } \\
\text { WIITE SPF } \\
\text { WHITE SPF } \\
\text { WHITE SPF }\end{array}$ & $\begin{array}{c}0,8 \\
\text { Plecebo } 0,8 \\
0,8 \\
\text { Plecebo } 0,8\end{array}$ & $1 . \bullet$ & $\begin{array}{l}- \\
- \\
-\end{array}$ & $\begin{array}{l}- \\
- \\
-\end{array}$ & $\begin{array}{l}16 \\
- \\
10 \\
-\end{array}$ & $\begin{array}{r}- \\
26 \\
16\end{array}$ & $\begin{array}{l}10^{3} \\
10^{3} \\
10^{3} \\
10^{3}\end{array}$ & $\begin{array}{l}1 \\
1 \\
7 \\
7\end{array}$ & $3,6,9$ & $\begin{array}{l}\text { LIVER } \\
\text { SPLEEN } \\
\text { CUT }\end{array}$ \\
\hline
\end{tabular}

LEGENC, LED - LELCOCYTE DIALYSATE, CFU - COCONY FOAMING WIIS, A - APPLICATION, C CONTROL

Tab. 1

to mice of the 5th and 6 th groups. Ten animals from each group ( 5 experimental and 5 controls) were killed on days $3,6,9$ and 30 post-infection.

\section{Testing for protective activity}

Testing for the minimum protective dose of DLE was done in 11 groups of mice (Tab. 2). The tests of protective activity for the individual fractions of Salmonellaspecific DLE were carried out in 24 groups of mice (Tab. 3). Twenty three representative fractions were selected for intraperitoneal inoculation of mice based upon 


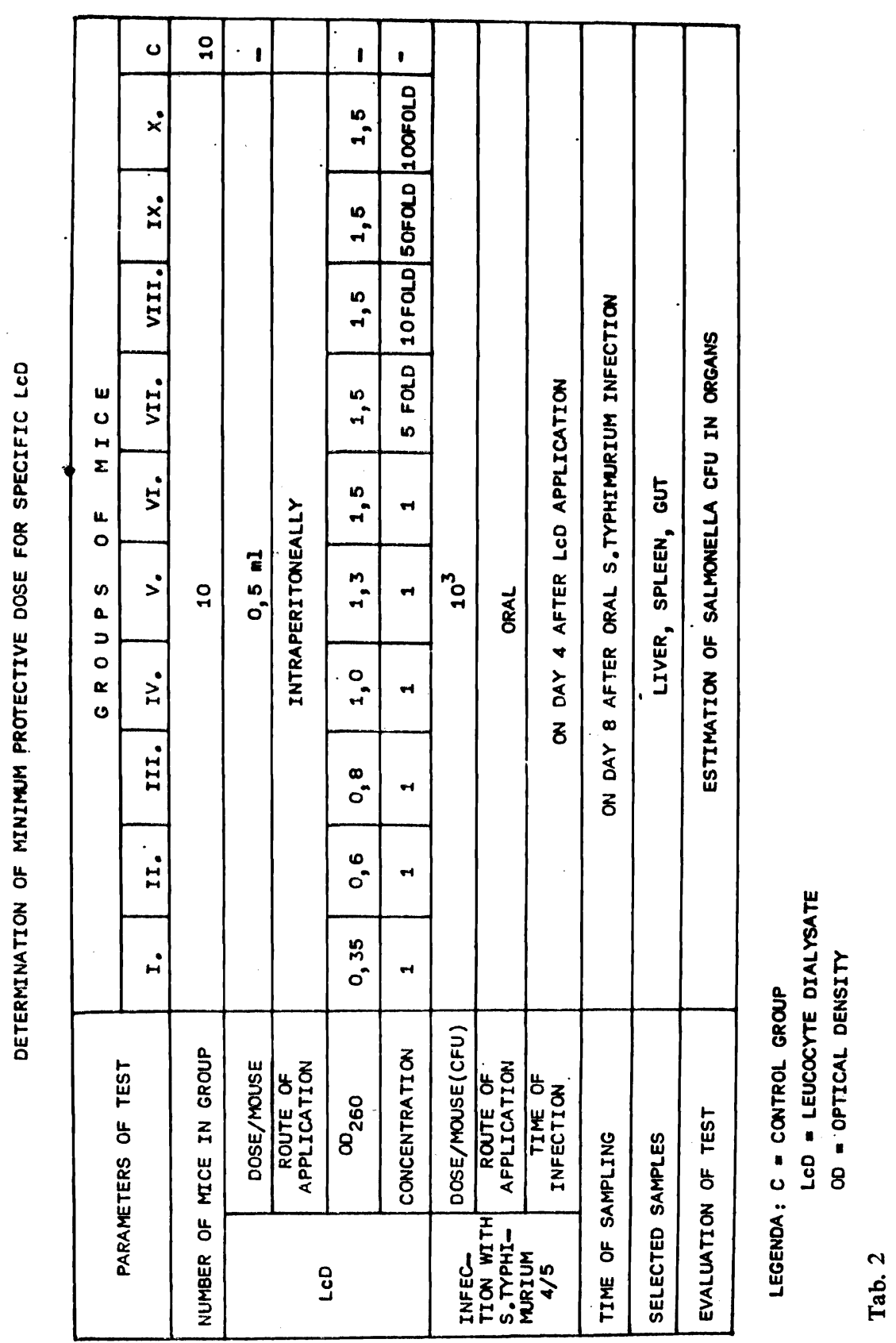




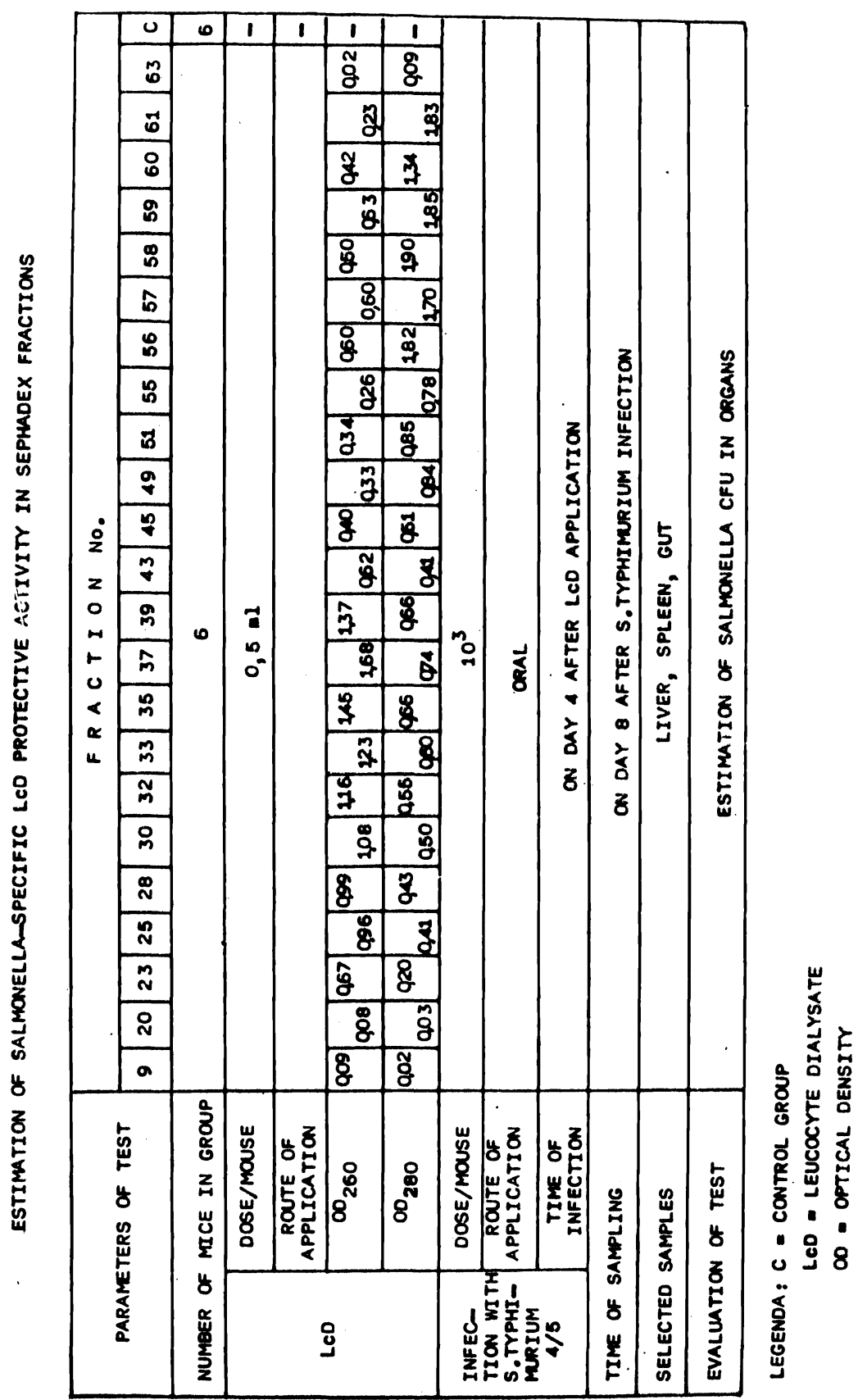

م 


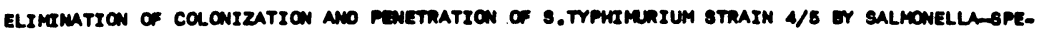
CIFIC LCD AS TESTED ON CONVWTIOULL WITE BPF MICE

\begin{tabular}{|c|c|c|c|c|c|c|c|}
\hline \multirow{4}{*}{$\begin{array}{l}\text { OAY } \\
\text { OF } \\
\text { KI- } \\
\text { LLING }\end{array}$} & \multirow[t]{4}{*}{ CReAM } & \multicolumn{3}{|c|}{ GROUP 1} & \multicolumn{3}{|c|}{$6200 P 2$} \\
\hline & & \multirow{2}{*}{\begin{tabular}{|l} 
\\
INFECTIONX AT \\
24 h AFTER LCD \\
APPLICATION
\end{tabular}} & \multirow{2}{*}{\begin{tabular}{|c|} 
C \\
INFECTIONX AT 24h \\
ANTER FuCEPO \\
APFLICATION
\end{tabular}} & \multirow{3}{*}{$\begin{array}{c}T \text { - Test } \\
\text { erenrfrcance }\end{array}$} & \multirow{2}{*}{$\begin{array}{l}\text { A } \\
\text { INFECTIONX CN } \\
\text { eAY } 7 \text { APTER LCD } \\
\text { APpLICATION }\end{array}$} & \multirow{2}{*}{ 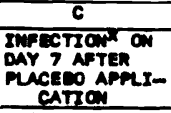 } & \multirow{3}{*}{$\begin{array}{c}T-\text { rest } \\
\text { erenzprcance }\end{array}$} \\
\hline & & & & & & & \\
\hline & & $x \pm$ ed $(\log )$ & $\bar{x} \pm$ ed $(2 \mathrm{es})$ & & $\bar{x} \pm$ ad $(\log )$ & $\bar{x} \pm$ od $(100)$ & \\
\hline 3 & $\begin{array}{l}1 \\
5 \\
6\end{array}$ & $3,12 \div 1,3$ & $4,00 \pm 0,03$ & $\begin{array}{l}p \\
\bullet \\
\bullet\end{array}$ & ? & $4,32 \geq 0,12$ & 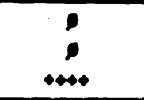 \\
\hline 6 & $\begin{array}{l}L \\
5 \\
6\end{array}$ & $\begin{array}{c}0 \\
4,04 \pm 0,8\end{array}$ & $\begin{array}{l}8,24 \pm 0,60 \\
8,14 \pm 0,70 \\
7,24 \pm 0,16\end{array}$ & $\begin{array}{l}\leftrightarrow \bullet \bullet \bullet \\
\leftrightarrow \bullet \bullet \bullet\end{array}$ & $2,70 \pm 0,77$ & $\begin{array}{l}6,34 \pm 0,76 \\
4,96 \pm 0,92 \\
7,40 \pm 0,86\end{array}$ & $\begin{array}{l}+4+4 \\
+4+4 \\
+4 t\end{array}$ \\
\hline - & $\begin{array}{l}1 \\
5 \\
6\end{array}$ & $3,03 \div 1,7$ & $\begin{array}{l}8,45 \pm 0,00 \\
4,94 \pm 1,21 \\
0,30 \pm 0,44\end{array}$ & $\begin{array}{c}\leftrightarrow+\infty \\
+\infty+\infty\end{array}$ & $2,17 \div 1,23$ & $\begin{array}{l}8,27 \pm 0,73 \\
4,30 \pm 0,07 \\
8,03 \pm 0,66\end{array}$ & t+4 \\
\hline 30 & $\begin{array}{l}L \\
5 \\
6\end{array}$ & $1,71 \div 1,04$ & $\begin{array}{l}1,82 \pm 1,4 \\
0,00 \pm 0,69 \\
4,00 \pm 1,48\end{array}$ & $\begin{array}{c}\bullet \bullet \bullet \bullet \\
\bullet \bullet \bullet \bullet \\
\bullet\end{array}$ & 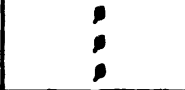 & $\begin{array}{l}2,16 \pm 0,02 \\
1,14 \pm 0,76 \\
3,70 \pm 0,08\end{array}$ & $\begin{array}{l}+\infty+\infty \\
+\leftrightarrow+\infty\end{array}$ \\
\hline
\end{tabular}

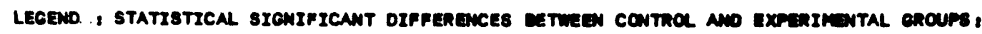

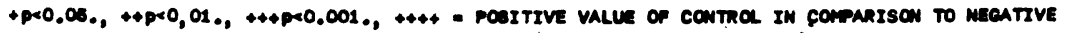

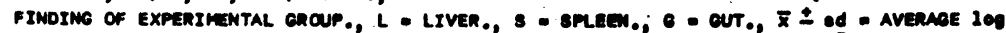

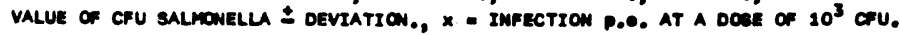
LCD - LEUCOCrTE dIALYSATE., A - APPLICATION., C - CONTRO.

Teb. 4

$\mathrm{OD}_{260}$ and $\mathrm{OD}_{280}$ (Fig. 2). After DLE application ( $0.5 \mathrm{ml}$ dose) mice were infected with $S$. typhimurium on day 4 . On day 8 post-infection mice were killed and necropsied. The difference in CFU between the experimental and control groups of mice allowed to calculate the inhibition of penetration and colonization of $S$. typhimurium strain used for challenge.

Evaluation of the test

Mice were killed and immediately subjected to necropsy. The bacterial counts of Salmonella (CFU) were determined in the parenchymatous organs and gut, respectively. The single counts of Salmonella CFU were calculated for $1 \mathrm{~g}$ of biological material, converted to logarithms and the mean value $(\bar{x})$ and the standard deviation (土 sd) were determined. Results were evaluated using Student's t-test.

\section{Results}

A. Testing for DLEs efficiency in conventional SPF white mice(Tab.4)

Mice from the 1st group were infected with virulent $S$. typhimurium strain $24 \mathrm{~h}$ after DLE application. The 2nd group of mice was infected on day 7. Mice of both groups were killed on days 3, 6, 9 and 30 from the time of infection. There was significant difference in the counts of Salmonella CFU present in the gastrointestinal tract of the 1st group of mice on day 3 post-infection as compared to controls ( $\mathrm{p}<$ $<0.05$ ). The presence of salmonellae has not been quantitatively detected in the parenchymatous organs and gut in the 2 nd group of mice. 


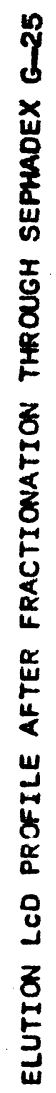

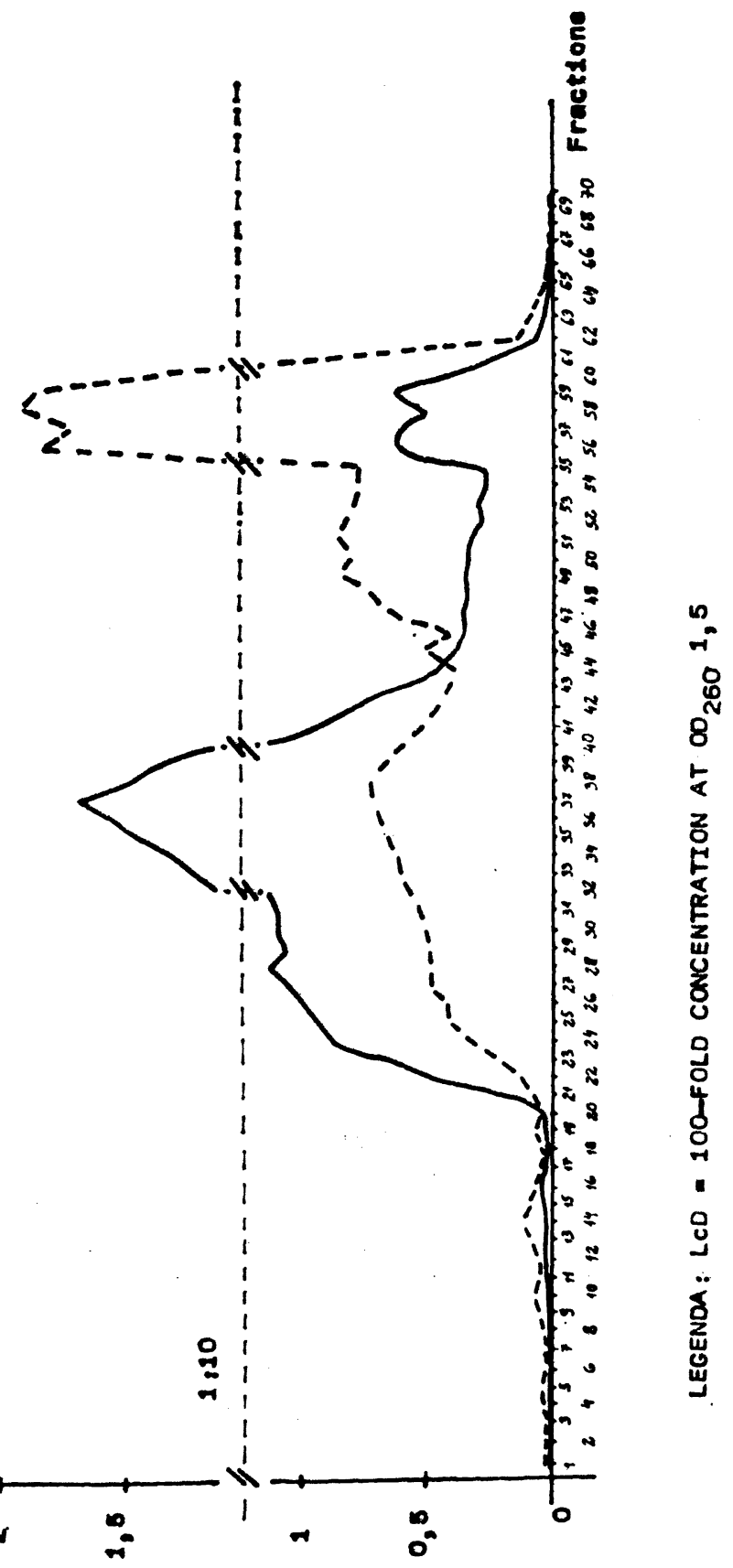

Ni 
On day 6 post-infection, salmonellae were not present in the parenchymatous organs of mice of the 1st and 2nd groups while the counts of salmonellae in controls expressed by a value of average logarithm were 5.94 and 5.34 in the liver and 5.54 and 4.95 in the spleen. In both control groups there was statistically significant difference in the counts of Salmonella CFU present in the gut $(p<0.001)$. Similar results were found on day 9 post-infection indicating the significant difference in the penetration of Salmonella into the parenchymatous organs of mice to which specific DLE was applied.

B. Testing for DLEs efficiency on C57BL/6 inbred mouse line (Tab. 5).

Testing of DLEs was performed on C57BL/6 inbred mouse line that is highly susceptible to Salmonella infection because of the defect in Ity gene.

The colonization and penetration of salmonellae were found in the control group of mice on day 3 post-infecti on. The penetration of Salmonella into the parenchymatous organs has been significantly reduced as determined by the counts of Salmonella CFU in mice of the 3rd and 4th groups $(p<0.001)$. The significant values were also recorded for Salmonella CFU in the gut $(\mathrm{p}<0.01$ in group 3, and $\mathrm{p}<0.01$ in group 4, respectively). On day 6 post-infection there were significant differences in the counts of CFU in the 3rd group of mice only in the parenchymatous organs ( $p<0.05$ in the liver and $p<0.01$ in the spleen) and in the same organs in group $4(\mathrm{p}<0.001)$.

The significant differences have not been found in the counts of Salmonella CFU in the 3rd group of mice on days 9 and 30 . In group 4 of mice there were significant differences in the liver $(p<0.05)$ and spleen $(p<0.01)$ on day 9 and also in the liver $(p<0.01)$, spleen $(p<0.05)$ and gut $(p<0.05)$ on day 30 , respectively.

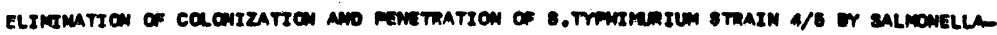

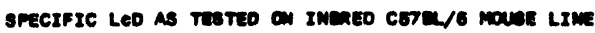

\begin{tabular}{|c|c|c|c|c|c|c|c|}
\hline \multirow{4}{*}{ 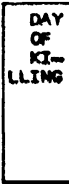 } & \multirow[t]{4}{*}{ ongan } & \multicolumn{3}{|c|}{$0.04 P 3$} & \multicolumn{3}{|c|}{$0 R 00 P 4$} \\
\hline & & $\mathbf{A}$ & $c$ & \multirow[b]{2}{*}{$T$ - TEST } & \multirow{2}{*}{ 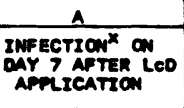 } & \multirow{2}{*}{ 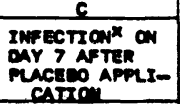 } & \multirow{3}{*}{$\begin{array}{c}T \text { - TEST } \\
\text { srenrf IcAMce }\end{array}$} \\
\hline & & $\begin{array}{l}\text { INFECTIONX AT } \\
24 \text { h AFTER LEO } \\
\text { APMLICATION }\end{array}$ & 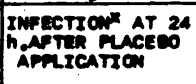 & & & & \\
\hline & & $z \pm$ ed $(2 e)$ & $I \pm$ od (2e1) & 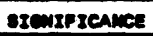 & $z \pm .0(200)$ & $\Sigma \pm$ od (2eq) & \\
\hline 3 & $\begin{array}{l}2 \\
3 \\
6\end{array}$ & $\begin{array}{c}0,30 \pm 0,10 \\
4,17 \pm 1,27\end{array}$ & $\begin{array}{l}8,67 \pm 0,48 \\
8,69 \pm 0,71 \\
6,79 \pm 0,78\end{array}$ & $\begin{array}{l}\leftrightarrow \leftrightarrow \bullet \\
\leftrightarrow \leftrightarrow \leftrightarrow \bullet \\
\bullet \bullet\end{array}$ & $\begin{array}{l}0,66 \pm 0,92 \\
4,04 \pm 0,43\end{array}$ & $\begin{array}{l}4,34 \pm 0,76 \\
6,20 \pm 0,43 \\
6,46 \pm 0,82\end{array}$ & 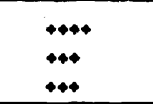 \\
\hline 6 & $\begin{array}{l}L \\
5 \\
G\end{array}$ & $\begin{array}{l}3,63 \pm 0,88 \\
2,79 \pm 0,89 \\
5,32 \pm 1,01\end{array}$ & $\begin{array}{l}5,04 \pm 0,40 \\
4,37 \pm 0,39 \\
4,34 \pm 2,60\end{array}$ & $\stackrel{\bullet}{\bullet}$ & $\begin{array}{l}2,36 \pm 0,47 \\
0,90 \pm 1,34 \\
3,97 \pm 0,47\end{array}$ & $\begin{array}{l}5,14 \pm 0,56 \\
3,98 \pm 0,44 \\
4,17 \pm 0,92\end{array}$ & $\stackrel{4+4}{+4}$ \\
\hline ? & $\begin{array}{l}L \\
8 \\
6\end{array}$ & $\begin{array}{l}6,40 \pm 1,41 \\
8,76 \pm 1,12 \\
6,44 \pm 0,24\end{array}$ & $\begin{array}{l}6,01 \pm 0,16 \\
6,10 \pm 0,42 \\
6,91 \pm 0,73\end{array}$ & 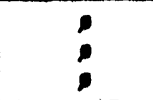 & $\begin{array}{l}8,78 \pm 0,68 \\
4,46 \pm 0,47 \\
6,47 \pm 0,86\end{array}$ & $\begin{array}{l}6,74 \pm 0,40 \\
6,30 \pm 0,32 \\
6,60 \pm 1,30\end{array}$ & $\stackrel{4}{\bullet}$ \\
\hline 30 & $\begin{array}{l}4 \\
5 \\
6\end{array}$ & $\begin{array}{l}3,63 \pm 1,71 \\
3,13 \pm 1,99 \\
5,13 \pm 1,66\end{array}$ & $\begin{array}{l}3,10 \pm 0,34 \\
2,30 \pm 0,80 \\
4,84 \pm 1,10\end{array}$ & 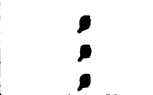 & $\begin{array}{l}1,69 \pm 0,48 \\
0,96 \pm 0,88 \\
2,00 \pm 0,38\end{array}$ & $\begin{array}{l}3,20 \pm 0,66 \\
2,60 \pm 0,30 \\
4,60 \pm 0,69\end{array}$ & 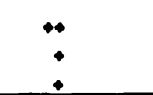 \\
\hline
\end{tabular}

LEGEND. I STATISTICAL SIEMIFICANT DIFFERENCES ENWEEN CONTRO ANO EXPERIMENTAL EROUPS,

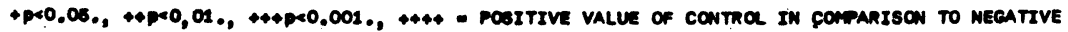

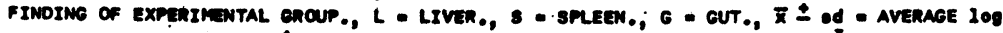

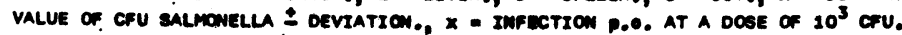
LED - LEUCOCYTE DIALYSATE., A - APMICATION., C - CONTRO.

Tab. 5 
C. Testing for DLEn efficiency on conventional SPF white mice(Tab.6)

From the results it followed that non-specific DLE did not inhibit penetration of salmonellae into the parenchymatous organs nor their counts in the gut. There was no statistically significant difference in the counts of Salmonella CFU in the single organs of experimental groups of mice in comparison with controls.

ELIMIMATION OF COCONIZATION ANO PENETRATION OF 8.THMIRURIUM STMAIN A/S ON MONGPECIFIC LCD AS TESTEO ON CONVEWTIONAL WHITE SPF MICE

\begin{tabular}{|c|c|c|c|c|c|c|c|}
\hline \multirow{4}{*}{$\begin{array}{l}\text { DaY } \\
\text { OF } \\
\text { KI- } \\
\text { LLING }\end{array}$} & \multirow[t]{4}{*}{ ORENN } & \multicolumn{3}{|c|}{ OROUP $B$} & \multicolumn{3}{|c|}{ GROUP 6} \\
\hline & & $A$ & c & & $\Lambda$ & c & \\
\hline & & $\begin{array}{l}\text { IMFECTIONX AT } \\
\text { 2A h AFTER LCD } \\
\text { APPLICATION }\end{array}$ & $\begin{array}{l}\text { INFECTION AT } 24 \\
\text { h,AFTER FUCETLO } \\
\text { APPLICATION }\end{array}$ & $T$ - TEST & $\begin{array}{l}\text { TWFECTICAY ON } \\
\text { DAY } 7 \text { AFTER LED } \\
\text { APMIXATION }\end{array}$ & 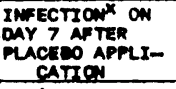 & $T$ - TEST \\
\hline & & $x \div \operatorname{od}(100)$ & $\bar{x} \pm$ od (Iog) & STCNIF ICANCE & $x \pm \operatorname{od}(200)$ & $\bar{x} \pm$ od $(100)$ & SIONIFICAMCE \\
\hline 3 & $\begin{array}{l}4 \\
3 \\
6\end{array}$ & $\begin{array}{l}1,85 \pm 0,39 \\
0,96 \pm 0,63 \\
1,95 \pm 0,86\end{array}$ & $\begin{array}{l}1,60 \pm 0,61 \\
0,64 \pm 0,90 \\
2,43 \pm 0,67\end{array}$ & $\begin{array}{l}p \\
p\end{array}$ & $\begin{array}{l}1,98 \pm 0,60 \\
1,57 \pm 0,99 \\
2,48 \pm 0,46\end{array}$ & $\begin{array}{l}1,90 \pm 0,44 \\
1,67 \pm 1,03 \\
2,47 \pm 1,18\end{array}$ & 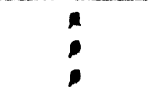 \\
\hline 6 & $\begin{array}{l}L \\
5 \\
6\end{array}$ & $\begin{array}{l}3,35 \pm 0,40 \\
2,67 \pm 0,80 \\
4,11 \pm 0,80\end{array}$ & $\begin{array}{l}3,71 \pm 0,46 \\
3,37 \pm 0,83 \\
4,47 \pm 0,07\end{array}$ & 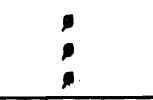 & $\begin{array}{l}3,38 \pm 0,72 \\
3,17 \pm 0,88 \\
3,97 \pm 1,16\end{array}$ & $\begin{array}{l}3,78 \pm 0,04 \\
3,50 \pm 0,63 \\
4,17 \pm 1,02\end{array}$ & p. \\
\hline 9 & $\begin{array}{l}L \\
8 \\
6\end{array}$ & $\begin{array}{l}3,74 \pm 0,71 \\
3,73 \pm 0,78 \\
4,81 \pm 1,27\end{array}$ & $\begin{array}{l}4,44 \pm 1,09 \\
4,30 \pm 1,11 \\
6,33 \pm 1,89\end{array}$ & 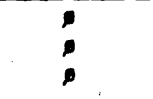 & $\begin{array}{l}3,68 \pm 1,68 \\
3,21 \pm 1,72 \\
4,67 \pm 1,70\end{array}$ & $\begin{array}{l}4,19 \pm 1,18 \\
3,76 \pm 0,78 \\
4,60 \pm 1,80\end{array}$ & 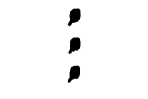 \\
\hline
\end{tabular}

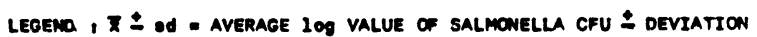

$x$ - imfection dose of $10^{3}$ CFU S.TYPhimintum

L- LIVER; S - SPLEEN; $O$ - GUT

LED - LEUCOCYTE DIALYSATE, A. APPLICATION LED, C - CONTRO

Tab. 6

D. Testing for minimum protective dose of DLEs (Tab. 7).

DLEs in the various concentrations (at required $\mathrm{OD}_{260}$ ) was administered i.p. to mice. DLE when applied to mice at $\mathrm{OD}_{260}=0.35-1.0$ did not induce any effect in the counts of Salmonella CFU. DLEs inoculated to mice at $\mathrm{OD}_{260}=1.3$ showed a significant difference in $(\mathrm{p}<0.05)$ Salmonella CFU in the gut but did not inhibit penetration of $S$. typhimurium strain into the liver and spleen. DLEs when applied at absorbance of 1.5 has shown a significant difference of CFU in the spleen and liver $(\mathrm{p}<0.05)$. 5 -fold concentrated DLEs with $\mathrm{OD}_{260}=1.5$ represented the minimum dose producing the significant difference in all the tested organs. DLEs doses that were 10-, 50- and 100-fold concentrated have induced significant differences in all tested organs.

E. Testing for protective activity of Salmonella-specific DLE present in Sephadex fractions

The elution profile obtained from 70 fractions of DLE is characterized by means of $\mathrm{OD}_{260}$ and $\mathrm{OD}_{280}$ absorbances (Fig. 2). Twenty three fractions representing the level of elution curve were assayed for protective activity (Tab. 8). 
The most significant inhibition of Salmonella CFU in the liver, spleen and gut $(p<0.001)$ was detected in the fraction no. 58, which was present in the maximum peak of $\mathrm{OD}_{280}$. The inhibition of Salmonella CFU in the liver, spleen and gut was found also in the fractions of maximum $\mathrm{OD}_{280}$ peak (fractions nos. 55-61). There were no significant differences in the fractions that showed the minimal and marked absorbance values of maximum $\mathrm{OD}_{260}$ peak (fractions nos. 9, 20, 23, 25, 28,63). The remaining fractions showed a partial inhibition of penetration and colonization of digestive tract as demonstrated in the liver and spleen (fractions nos. 30, 35, 37, $39,43,45,51)$.

\section{Discussion}

The tests for transfer of immunity by means of DLE were done on mouse model by many authors. Li Zailian (1987) applied the porcine specific transfer factor into footpad of mice primed with the viral antigen of encephalitis B. He observed the lymphocyte infiltration in the footpad tissue as compared to the control group. Huang et al. (1987) reported on protective immunity to HSV 1 following specific TF application to BALB/c mouse line. Mayer et al. (1987) studied specificity of cytotoxic cells inducing activity in dialyzate of splenocytes of mice sequentially immunized by three live viruses. After TF application to CBA mice, Krejčí et al. (1987) have found the passive transfer of tolerance to contact sensitivity by transfer factor. In our work we presented results obtained on mouse model for testing of immunity induced by specific DLE in the course of salmonellosis. From the results it followed that our DLE preparation (10-fold concentrated; $\mathrm{OD}_{\mathbf{2 6 0}}=1.8$ for DLEs) was able to prevent or markedly reduce the penetration and colonization of salmonellae. The differences observed in the counts of Salmonella CFU in the digestive tract of the 1 st and 2nd groups and also in the 3rd and 4th groups of mice suggested stronger inhibition of infection on day 7 following specific DLE application. This finding may be associated with potentiation of antigen-dependent DNA synthesis in mature lymphocytes (Arala-Chaves et al. 1976).

Non-specific DLE did not induce any immunity in SPF white mice, i. e. the mouse model represents the sensitive indicator of specificity in the case of Salmonella infection, however, it is not applicable for the detection of efficiency in non-specific DLE.

The mechanism of TF effect is indicated by results achieved in C57BL/6 inbred mouse line defective in Ity gene, which results in the dysfunction of the activity of macrophages (Cohen et al. 1976). As it can be seen from the dynamics of Salmonella infection, the more rapid development of this disease occurred in inbred line of mice than in conventional white mice. Resuspending of the freeze-dried specific DLE according to $\mathrm{OD}_{260}$ allowed determination of its minimum inhibitory concentration inducing such immunity, that eliminated to a significant extent not only the Salmonella penetration but also colonization of digestive tract of mice infected with virulent $S$. typhimurium strain. We can recommend, that the minimum inhibitory concentration of DLE that induces statistically significant reduction in the counts of Salmonella CFU present in the parenchymatous organs and gut on the level of $p<0.01$ significance, may be considered the unit of specificity or of activity of the respective substrate.

Mayer et al. (1987) reported on the gel chromatography fractionation of DLE isolated from the spleens of mice immunized with flavivirus. The authors detected tha highest inductive activities of DLE in the 2nd and 3rd peak, respectively. Our results are in agreement with those obtained by Andron and Ascher (1977) who 
THE MINIMUM INHIBITION DOSE OF ANTI-SALMONELLA SPECIFIC LEUCOCYTE DIALYSATE

\begin{tabular}{|c|c|c|c|}
\hline \multirow{2}{*}{$\begin{array}{l}\text { LCD. } \\
\infty_{260}\end{array}$} & \multirow{2}{*}{ ORGAN } & $\begin{array}{l}\text { THE MEAN CFU OF } \\
\text { SALMONELLA }\end{array}$ & \multirow{2}{*}{\begin{tabular}{|l|}
\multicolumn{1}{|c}{ T-TEST } \\
SIGNIFI- \\
CANCE OF \\
OIFFERENCE
\end{tabular}} \\
\hline & & $\bar{x} \pm$ od $(\log )$ & \\
\hline \multirow{3}{*}{0,35} & $L$ & $4,75 \pm 0,79$ & 0 \\
\hline & s & $4,15 \pm 0,95$ & 0 \\
\hline & G & $6,63 \pm 0,65$ & 0 \\
\hline \multirow{3}{*}{0,6} & $L$ & $4,71 \geq 0,68$ & 0 \\
\hline & $\mathbf{s}$ & $3,71 \pm 1,06$ & 0 \\
\hline & G & $6,33 \pm 0,68$ & 0 \\
\hline \multirow{3}{*}{0,8} & $L$ & $4,66 \geq 0,72$ & 0 \\
\hline & $\mathbf{s}$ & $4,05 \pm 0,78$ & 0 \\
\hline & G & $6,18 \pm 0,39$ & 0 \\
\hline \multirow{3}{*}{1,0} & L & $3,75 \pm 0,74$ & 0 \\
\hline & s & $3,39 \pm 0,60$ & 0 \\
\hline & $\mathbf{G}$ & $5,61 \pm 0,77$ & 0 \\
\hline \multirow{3}{*}{1,3} & $L$ & $4,00 \pm 0,52$ & 0 \\
\hline & $\mathbf{s}$ & $3,25 \pm 1,01$ & 0 \\
\hline & 6 & $5,34 \pm 0,61$ & + \\
\hline \multirow{3}{*}{1,5} & $L$ & $3,17 \pm 0,68$ & 0 \\
\hline & $\mathbf{s}$ & $2,28 \pm 0,80$. & + \\
\hline & G & $4,98 \pm 0,81$ & + \\
\hline \multirow{3}{*}{$5 x^{1,5}$} & $L$ & $2,73=0,73$ & + \\
\hline & $s$ & $1,78 \pm 0,73$ & +4 \\
\hline & $G$ & $5,16 \pm 0,35$ & $+t$ \\
\hline \multirow{3}{*}{$\frac{1}{1} b_{x}^{5}$} & $L$ & $1,86 \pm 1,08$ & $+t$ \\
\hline & ș & $1,11 \pm 0,96$ & $+t$ \\
\hline & $G$ & $4,40 \pm 0,66$ & ++ \\
\hline \multirow{3}{*}{$\frac{1}{56} x^{5}$} & $L$ & $1,24 \geq 1,05$ & $+4+$ \\
\hline & s & $0,62 \pm 0,70$ & +++ \\
\hline & G & $4,25 \pm 1,01$ & ++ \\
\hline \multirow{3}{*}{$\begin{array}{l}185 \\
180 x\end{array}$} & $L$ & $1,27 \pm 1,03$ & $++t$ \\
\hline & s & $0,80 \pm 0,64$ & $+t+$ \\
\hline & G. & $4,00 \pm 0,60$ & +++ \\
\hline \multirow{3}{*}{ CONTROL } & $L$ & $4,18 \pm 1,15$ & - \\
\hline & $\mathbf{s}$ & $3,63 \pm 1,20$ & - \\
\hline & G & $6,31 \pm 0,79$ & - \\
\hline
\end{tabular}

LEGENDA; THERE WERE STATISTICALLY SIGNIFICANT OIFFERENCES BETMEEN CONTROL AND EXPERIMENTAL GROUP: + p 0.05. $++p<0.01$. $+++p<0.001$. L-LIVER . S -SPLEEN G-GUT. $\bar{x}:-$ THE MEAN IOg VALUE OF SALMONELLA CFU — DEVIATION.

Tab. 7 
THE PROTECTIVE ACTIVITY OF SEPHADEX FRACTIONS OBTAINED FROM SALMONELLA-SPECIFIC LCD

\begin{tabular}{|c|c|c|c|c|c|c|}
\hline \multirow{4}{*}{$\begin{array}{l}\text { FRAC } \\
\text { TION } \\
\text { No. }\end{array}$} & \multicolumn{3}{|c|}{ THE MEAN CFU OF SALMONELLA } & \multicolumn{3}{|c|}{$T$ - TEST } \\
\hline & \multicolumn{3}{|c|}{$x \pm$ od $(\log )$} & \multicolumn{3}{|c|}{ SIGNIFICANCE OF DIFFERENCE } \\
\hline & \multirow{2}{*}{$L$} & \multirow{2}{*}{$\mathbf{s}$} & \multirow{2}{*}{ G } & $L$ & $\mathrm{~s}$ & G \\
\hline & & & & $\mathbf{p}$ & $\mathbf{p}$ & $p$ \\
\hline 9 & $3,13 \pm 1,20$ & $2,68 \pm 1,17$ & $5,48 \pm 1,07$ & 0 & $\overline{0}$ & 0 \\
\hline 20 & $3,45 \pm 0,94$ & $2,90 \pm 0,57$ & $5,50 \pm 0,80$ & 0 & 0 & 0 \\
\hline 23 & $3,25 \pm 1,17$ & $3,08 \pm 0,77$ & $5,29 \pm 1,50$ & 0 & 0 & 0 \\
\hline 25 & $3,33 \pm 0,60$ & $3,11 \pm 0,96$ & $5,37 \pm 0,82$ & 0 & 0 & 0 \\
\hline 28 & $3,08 \pm 0,97$ & $2,69 \pm 0,77$ & $5,44 \pm 0,88$ & 0 & 0 & 0 \\
\hline 30 & $3,25 \pm 0,93$ & $3,08 \pm 0,50$ & $5,21 \pm 0,88$ & 0 & 0 & $<0,05$ \\
\hline 32 & $2,40 \pm 0,85$ & $2,16 \pm 0,67$ & $5,38 \pm 0,63$ & $<0,01$ & $<0,05$ & $<0,05$ \\
\hline 33 & $2,56 \pm 0,89$ & $2,15 \pm 0,82$ & $5,25 \pm 0,87$ & $<0,01$ & $<0,05$ & $<0,05$ \\
\hline 3.5 & $2,93 \pm 0,64$ & $2,93 \pm 0,72$ & $5,79 \pm 0,70$ & $<0,5$ & 0 & 0 \\
\hline 37 & $2,58 \pm 0,82$ & $2,69 \pm 0,55$ & $5,67 \pm 0,56$ & $<0,01$ & 0 & 0 \\
\hline 39 & $2,75 \pm 0,84$ & $2,65 \pm 0,80$ & $5,86 \neq 0,51$ & $<0,05$ & 0 & 0 \\
\hline 43 & $2,71 \pm 0,71$ & $2,05 \pm 0,72$ & $0,31 \pm 0,69$ & $<0,01$ & 0 & $<0,05$ \\
\hline 45 & $2,85 \pm 0,80$ & $2,32 \pm 1,28$ & $5,05 \pm 0,43$ & $<0,05$ & 0 & $<0,001$ \\
\hline 49 & $2,77 \pm 0,84$ & $2,03 \pm 0,79$ & $5,11 \pm 0,50$ & $<0,05$ & $<0,01$ & $<0,001$ \\
\hline 51 & $2,72 \pm 0,79$ & $2,61 \pm 0,87$ & $4,99 \pm 0,45$ & $<0,08$ & 0 & $<0,001$ \\
\hline 55 & $2,64 \pm 0,79$ & $2,02 \pm 1,08$ & $4,76 \pm 0,71$ & $<0,01$. & $<0,05$. & $<0,01$ \\
\hline 56 & $1,67 \pm 1,01$ & $1,12 \pm 1,01$ & $4,81 \pm 0,68$ & $<0,001$. & $<0,01$ & $<0,01$ \\
\hline 57 & $2,32 \pm 1,00$ & $1,66 \pm 0,92$ & $4,50 \pm 0,76$ & $<0,01$ & $<0,01$ & $<0,001$ \\
\hline 58 & $2,13 \pm 0,68$ & $1,29 \pm 0,81$ & $4,42 \pm 0,68$ & $<0,001$ & $<0,001$ & $<0,001$ \\
\hline 59 & $1,67 \pm 1,04$ & $1,21 \pm 1,06$ & $4,52 \pm 0,92$ & $<0,001$ & $<o p$. & $<0,01$ \\
\hline 60 & $2,25 \pm 0,96$ & $1,59 \pm 0,91$ & $4,87 \pm 0,48$ & $<0,01$ & $<0,01$ & $<0,001$ \\
\hline 61 & $2,53 \pm 1,00$ & $2,12 \pm 0,65$ & $4,66 \pm 0,71$ & $<0,5$ & $<0 ; 01$ & $<0,01$ \\
\hline 63 & $3,63=0,73$ & $2,96=0,65$ & $5,73 \pm 0,54$ & 0 & 0 & 0 \\
\hline c & $4,00 \pm 0,64$ & $3,35 \pm 0,64$ & $6,18 \pm 0,39$ & & & \\
\hline
\end{tabular}

Legemoa: $\bar{x} \pm$ od - THE MEAN log Value of salmonella CFu \pm deviation., L = LIVER., S - SPLEEN., G = GUT

Tab. 8 
showed a similar protective activity of the single fractions eluted during the gel chromatography of DLE isolated from human leucocytes.

Other authors suggested differences in DLE activity dependent on the origin of DLE obtained from the peripheral blood lymphocytes (Borvák et al. 1987) or porcine spleens (Li Zailian 1987). The differences have been also detected within the spectrum of active fractions purified by means of the gel chromatography.

Using the mouse model we have estimated the highest protective activity of Salmonella-specific DLE in the fraction no. 58. This corresponded to (i) 10-fold concentration at $\mathrm{OD}_{260}=0.6$, and (ii) 10 -fold concentration at $\mathrm{OD}_{280}=1.7$. The given extinction inhibited, in a significant degree, penetration of salmonellae into the parenchyma organs and their multiplication in the digestive tract.

Profile of the elution curve indicated, that the fractions with maximum absorbance at $\mathrm{OD}_{260}$ gave either low or no protective activity. On the other hand, the fractions with maximum $\mathrm{OD}_{280}$ have showed the highest protective activity. Characteristics of low-molecular components of DLE is given by index: $\mathrm{OD}_{260} / \mathrm{OD}_{280}=1.8$. This index ranged from 0.26 to 0.34 in the fractions showing the high protective activity. In contrast, the index was in the range of $2.05-3.2$ in the intact fractions. From the index of absorbance values it is possible to deduce that a marked protective activity is ensured by DLE components with molecular weight of approximately 2000-3000 daltons that are represented by oligoribonucleotides or oligoribonucleophosphopeptides responsible for the transfer of specific immunity to Salmonella infection. Our results are supported by data from other authors who observed the transfer of antigen-specific cell-mediated immune response both in vitro and in vivo (Dunnick and Bach 1976; B urger et al. 1979; Padd ock et al. 1983; Wil son et al. 1982).

So far obtained results suggest that: (1) mouse model is suitable for testing of the protective activity of specific DLE and for the determination of the minimum inhibitory dose against salmonelosis. (2) isolated Salmonella-specific DLE is formed by a mixture of fractions with various activities affecting the penetration of salmonellae into the parenchymatous organs and colonization of gastrointestinal tract as well. (3) the index ratio of $\mathrm{OD}_{260}$ to $\mathrm{OD}_{280}$ characterizing low-molecular components in Sephadex fractions shows different values than in the case of crude DLE preparation.

\section{Využitie myšiẹho modelu pre stanovenie protekěnej aktivity špecifického salmonelového leukocytárneho dialyzátu}

Špecifický leukocytárny dialyzát $\left(\mathrm{LCD}^{\mathrm{s}}\right)$ bol pripravený z leukocytov periférnej krvi, $\mathrm{z}$ mezenteriálnych lymfatických uzlín a slezín teliat, vakcinovaných a následne infikovaných virulentným kmeňom $S$. typhimurium. Nešpecifický $\operatorname{LcD}\left(\mathrm{LcD}^{\mathrm{n}}\right)$ bol pripravený z lymfatických uzlín výkrmových býkov. Na SPF bielych myšiach ako aj myšiach inbrednej línie C57BL/6 po aplikácii LcD a následnej infekcii kmeňom S. typhimurium bola testovaná inhibícia penetrácie salmonel do pečene, sleziny, ako aj kolonizácie tráviaceho traktu. U bielych myší aplikácia $\mathrm{LcD}^{\mathrm{s}}$ navodila výraznú inhibíciu až elimináciu penetračnej schopnosti virulentného kmeňa $S$. typhimurium. $U$ myší linie C57BL/6 $\mathrm{LcD}^{s}$ čiastočne inhiboval pomnoženie salmonel $\mathrm{v}$ pečen $\mathrm{i}$ a slezine. $\mathrm{LcD}^{\mathrm{n}}$ neinhiboval penetráciu a kolonizáciu salmonel.

Štandardizácia $\mathrm{LcD}$ preparátov bola vykonaná meraním $\mathrm{OD}_{260}, \mathrm{LcD}^{\mathrm{s}} \mathrm{OD}_{260}=$ $=1.5$, desatnásobne zahustený zaistil inhibíciu až elimináciu penetračnej a kolonizačnej schopnosti $S$. typhimurium.

Frakcionácia $\mathrm{LcD}^{\mathrm{s}}$ cez Sephadex G.25 potvrdila heterogenitu frakcií v protekcii 
voči salmonelovej infekcii. Testovaný index pomerov $\mathrm{OD}_{260} \mathrm{k} \mathrm{OD}_{280}$ sephadexových frakcií sa liši od indexu LcD preparátu.

\section{Применение мышей в качесте модели для проверки специфического салмонеллезного лейкоцитарного диализата}

Специфический лейкоцитарный диализат ( $\mathrm{LCD}^{s}$ ) был приготовлен из мезентериальных лимфатических узлов и селезенки телят, вакцинированных и споследствии инфицированных вирулентных штаммом $S$. typhimurium. Неспецифический $\left(\mathrm{LCD}^{\mathrm{n}}\right)$ лейкоцитарный диализат был подготовлен из мезентериалных лимфатических узлов быков. На SPF белых мышей, а также мышей имбредной линии C57BL/6 после ввода лейкоцитарного диализата и последующей инфекции штаммом S. typhimurium проверяли ингибицию проникновения салмонел в печень, селезенку, а также колонизацию пищеварительнопо тракта. Ввод лейкоцитарного диализата $\left(L C D^{s}\right)$ у белых мышей существенно тормозит и даже исключает способность к проникновению вирулентного штамма $S$. typhimurium. У мышей линии $\mathrm{C} 57 \mathrm{BL} / 6$ лейкоцитарный диализат лиш частично тормозит размножение вирулентного штамма Salmonella typhimurium в печени и селезенке. $\mathrm{LcD}^{\mathrm{s}}$ неинтибировал проникновение и колонизацию салмонелл в печень и селезенку.

Определение единицы активности лиофилиэированного LCD, проверяемой на модели мышей, проводили измерением оптической плотности при 260 нм (ОП 260). Интраперитонеально вводимый раствор специфического ОП 260 1, 5, сгушенный в десять раз, обеспечил выразительное торможение и даже исключение пенетрирующей и колонизационной способности вирулентного штамма S. typhimurium.

Фракционирование LCD по отношению к сальмонеллезной инфекции через сефадекс Г-25 подтвердило гетерогенность фракций в защите от сальмонеллезной инфекции.

\section{References}

ABLIN, J. R.: Transfer factor: Specific and non-specific effects and chemical characteristics of dialyzable leucocyte lysates (DLL)., Part. I. Allergol. et Immunopathol., 53, 1980: 53-60.

ANDRON, L. A. - ASCHER, M. S.: Transfer factor in vitro: Chromatography of components that enhance antigen induced lymphocyte proliferation. J. Cell. Immunol., 21, 1977: 157-165.

ARALA-CHAVES, M. P. - RAMOS, M. T. F. - PORTO, M. T.: Specific and non-specific effects of TF-dialyzable leucocyte extracts. In: Ascher, M. S., Gottlieb, A. A. and Kirkpatrick, C. H. editors: Transfer factor: Basic properties and clinical applications. Acad. Press. Inc. New York, 1976: 276-282.

ARAlA-CHAVES, M. P. - SIlVA, A. - PORTO, M. T. - PICOTO, A. - RAMOS, M. T. F. - FUDENBERG, H. H.: In vitro and in vivo studies of the target cell for dialyzable leucocyte extracts. Clin. Immunology and Immunopathology 8, 1977: 430-447.

BORVÁK, J. - MAYER, V. - KOTULIAK, A.: Lysed human leucocyte ultrafiltrate: Analytical studies by chromatographic methods. In: Proceedings Fifth International Symposium on Transfer Factor. Bratislava, 1987: 64-83.

BURGER, D. R. - WAMPLER, P. A. - VANDENGARK, A. A. - REGAN, D. H.: A structural model for human transfer factor. Discussion paper. Ann. N. Y. Acad. Sci., 332, 1979: $236-240$.

COHEN, L. - LEVIN, A. S. - FRANKE, W.: Requirement of precommitted cells as targets 
for the augmentation of lymphocyte proliferation by leucocyte dialysates. J. Exp. Med., 143, 1976: 791.

DUNNICK, W. - BACH, F. H.: Guinea pig 》transfer factor« in vitro. Physico-chemical properties and partial purification. In: Transfer factor: Basic Properties and Clinical Applications, 1976: $185-195$.

FUDENBERG, H. H. et al.: Dialyzable leucocyte extracts (transfer factor). In: Wigzell F. and Wigzell H. eds.: Thymus, thymic hormones and T-lymphocytes. Acad. Press. Inc. London, 1980: $315-326$.

FUDENBERG, H. H.: Transfer factor: Past, Present and Future. In: Proceedings of Fifth International Symposium on Transfer factor. Bratislava, 1987: 20-49.

HUANG, L. L. - VAN ZHI-FANG - SU CHENG ZHI: Nature and antigen-specific activities of transfer factor against Herpes simplex type 1. In: Proc. Fifth International Symposium on Transfer Factor. Bratislava, 1987: 234-246.

KHAN, A. - KIRKPATRICK, C. H. - HILL, N. O.: eds.: Immune regulators in transfer factor. Academic Press, Inc. New York, 1979.

KREJČ́, J. - PEKÁREK, J. - ČECH, K. - SLÁDEČEK, M.: The passive transfer of tolerance to contact sensitivity by transfer factor. In: Proc. Fifth International Symposium on Transfer factor. Bratislava, 1987: 246-256.

LEVIN, A. S.: Wiscott-Aldrich syndrome: A genetically determined cellular immunologic deficiency: clinical and Laboratory responses to therapy with transfer factor. Proc. Nat. Acad. Sci. USA, 67, 1970: 821.

LI ZAILIAN: Studies on porcine spleen cell dialyzates. In: Proc. Fifth International Symposium on Transfer Factor, Bratislava, 1987: 84-91.

MAYER, V. - GAJDOŠVVA, E. - ZACHAR, V. - BAČÍK, J. - ORAVEC, C.: Specificity of cytotoxic cells inducing activity in dialysates of splenocytes of mice sequentially immunized by three live viruses. In: Proc. Fifth International Symposium on Transfer Factor. Bratislava, 1987: $246-256$.

PADDOCK, G. V. - WILSON, G. B. - WILIAMS, A. M. - FUDENBERG, H. H.: Human transfer factor: Exogenous labeling purification and role of ribonucleoic acid segment. In: C. H. Kirkpatrick, D. R. Burger and H. S. Lawrence. Immunology of Transfer Factor, Acad. Press, New York, 1983: 31.

WILSON, G. B. - WELCH, T. M. - FUDENBERG, H. H.: Human transfer factor in guinea pigs: partial purification of the active component. In: Ascher, M. S., Gottlieb, A. A., Kirkpatrick, C. M., editors: Transfer factor: Basic properties and clinical applications, Acad. Press, Inc. New York, 1976.

WILSON, G. B. - PADDOCK, G. V. - FUDENBERG, H. H.: Bovine »transfer factor«: an oligoribonucleopeptide which initiates antigen-specific lymphocyte responsivenes. Thymus, 4, 1982: 335.

WILSON, G. B. - METACALF, J. F. - FUDENBERG, H. H.: Treatment of Mycobacterium fortuitum pulmonary infection with »transfer factor« (TF): New methodology for evaluating TF potency and predicting clinical response. Clin. Immunol. Immunopathol., 23, 1982: $478-491$.

WILSON, G. B. - NEWELL, R. T. - BURDASH, N. M.: Immunochemical and physicalchemical evidence for the presence of thymosin alpha-1-peptide in dialyzable leucocyte extracts. In: Kirkpatrick, C. H., Lawrence, H. S. and Burger, D. R.: Fourth International Transfer Factor Workshop in Denver. Academic Press, Inc. New York, 1983.

WILSON, G. B. - FUDENBERG, H. H.: Is controversy about »transfer factor « therapy nearing to an end? Immunol. Today, 4, 1983: 157. 